\title{
Pandemik Covid-19: Analisis Perencanaan Pemerintah dan Masyarakat dalam Berbagai Upaya Pencegahan
}

\section{COVID-19 Pandemic: Analysis of Government and Community Planning in Various Prevention Measures}

\author{
Idah Wahidah* \\ Prodi Ilmu Administrasi Publik FISIP UIN Sunan Gunung Djati Bandung Jawa Barat, 40614 \\ e-mail: iddah@uinsgd.ac.id \\ Muhammad Andi Septiadi \\ Prodi Ilmu Politik FISIP UIN Sunan Gunung Djati Bandung Jawa Barat, 40614 \\ e-mail: septiadi.andi90@uinsgd.ac.id \\ M. Choerul Adlie Rafqie \\ Prodi Ilmu Politik FISIP UIN Sunan Gunung Djati Bandung Jawa Barat, 40614 \\ e-mail: arafqie2603@gmail.com \\ Nur Fitria Salsabila Hartono \\ Prodi Ilmu Politik FISIP UIN Sunan Gunung Djati Bandung Jawa Barat, 40614 \\ e-mail: nurfitriasalsabila30@gmail.com \\ Raihan Athallah \\ Prodi Ilmu Politik FISIP UIN Sunan Gunung Djati Bandung Jawa Barat, 40614 \\ e-mail: raihanathallah30@gmail.com
}

\begin{abstract}
The new epidemic phenomenon called Covid-19 which originated in Wuhan, China continues to increase its victims. This article aims to provide an explanation of the new outbreak and analyze planning management regarding the important role of government policies that must synergize with the community by 4 strategies from the government, namely promotive, preventive, curative and social safety net strategies which will later impact on strategies that are can the government apply in passing a pandemic disaster. The method used in writing this article is a qualitative method that explains something based on data and numbers narrated in concluding sentences, besides that, the writing of this article is library research, collecting data through available documents. and using triangulation techniques in analyzing the data that has been collected. The results obtained are the role of the government constantly reminding and asking for the participation of the community to achieve maximum government policy results, the need for the role of the community in an effort to overcome the pandemic to carry out all existing policies so that there is synergy to break the chain of spread of the COVID-19 virus and It was also found that the Head of RT / RW is one way that can assist the government in carrying out synergy with the community. This research is expected to be a source of reference for the government in planning the next policy in the process of overcoming the COVID-19 pandemic.
\end{abstract}

Keywords: COVID-19, Pandemic, government, Planning, community, synergy.

\begin{abstract}
ABSTRAK
Fenomena wabah baru bernama Covid-19 yang berasal dari Wuhan, Tiongkok terus menerus bertambah korbannya. Artikel ini bertujuan untuk memberikan penjelasan tentang wabah baru serta menganalisis manajemen perencanaan mengenai peran penting kebijakan pemerintah yang harus bersinergis dengan masyarakat oleh 4 strategi dari pemerintah, yaitu strategi promotif, preventif, kuratif beserta jaring pengaman sosial yang nanti nya akan berdampak pada strategi strategi yang dapat pemerintah terapkan dalam melewati musibah pandemic. Metode yang digunakan dalam penulisan artikel ini merupakan metode kualitatif yang bersifat menjelaskan sesuatu berdasar pada data dan angka yang dinarasikan dalam kalimat - kalimat simpulan, selain itu, penulisan artikel ini merupakan penelitian pustaka (library research), Melakukan pengumpulan data melalui dokumen-dokumen yang tersedia serta menggunakan tekhnik triangulasi dalam melakukan analisis dari data - data yang telah dikumpulkan. Hasil yang didapat yaitu peran pemerintah tak henti-hentinya mengingatkan dan meminta peran serta masyarakat untuk pencapaian hasil kebijakan pemerintah yang maksimal,
\end{abstract}

\section{${ }^{*}$ Corresponding author}


diperlukannya peran masyarakat dalam upaya menangulangi pandemi untuk melakukan semua kebijakan yang ada agar adanya kesinergisan untuk tujuan memutuskan rantai penyebaran virus COVID-19 serta ditemukan pula bahwa Ketua RT/RW merupakan salah satu jalan yang dapat membantu pemerintah dalam menjalankan sinergitas dengan masyarakat. Penelitian ini diharapkan dapat menjadi sumber referensi bagi pemerintah dalam merencanakan kebijakan berikutnya dalam proses mengatasi pandemic COVID-19.

Kata Kunci: COVID-19, Pandemi, pemerintah, Perencanaan, masyarakat, sinergitas.

\section{PENDAHULUAN}

Dewasa ini, dunia sedang diguncang oleh pandemik hebat bernama Covid-19 (Corona Virus Disease). Peningkatan dari hari kehari jumlah pasien terinfeksi virus Covid-19 sudah sulit dikendalikan diperlukannya suatu perencanaan yang jelas dan lugas dari pemerintah untuk menangulangi permasalahan ini. Coronavirus sendiri merupakan sekumpulan virus yang berasal dari subfamili Orthocronavirinae dalam keluarga Coronaviridae dan ordo Nidovirales (Yunus \& Rezki, 2020). Virus ini dapat menyerang hewan dan juga manusia dan pada manusia gejalanya berupa infeksi yang serupa dengan penyakit SARS dan MERS, hanya saja Covid-19 bersifat lebih masif perkembangannya. Indonesia juga merupakan salah satu negara yang terdampak wabah yang satu ini. Oleh karena itu, perlu tindakan pemerintah dan kesadaran penuh dari masyarakat agar angka penyebaran virus ini dapat ditekan. Namun, dalam penelitian yang dilakukan oleh (Arum, 2020), Pemerintah Indonesia masih hanya melakukan penanganan berupa pembatasan sosial saja (social distancing). Padahal banyak kalangan yang menganggap bahwa lebih efektif menerapkan sistem karantina wilayah atau lockdown untuk mencegah penyebaran virus ini agar tidak menginfeksi lebih banyak orang (Nurhalimah, 2020), sedangkan pembatasan sosial masih rawan penyebarannya disebabkan banyak masyarakat yang tidak mau mengikuti karena pada hakikatnya hal tersebut hanya sekadar imbauan dan tidak ada sanksi berat yang bisa membuat masyarakat patuh. Selaras dengan itu, penelitian dari (Telaumbanua, 2020) menyebutkan bahwa pemerintah dituntut untuk menangani ancaman nyata Covid-19. Jawaban sementara pemerintah terhadap tuntutan tersebut adalah UndangUndang Nomor 6 Tahun 2018 terkait Kekarantinaan Kesehatan. Keputusannya adalah pemerintah pusat tidak memberlakukan karantina wilayah atau lockdown melainkan memberlakukan Pembatasan Sosial Berskala Besar (PSBB) sebagaimana diatur dalam PP Nomor 21 Tahun 2020 dan juga melakukan tindakan tes massal menggunakan alat rapid test yang jika seseorang dinyatakan hasil tesnya reaktif maka akan dilakukan swab test untuk memastikan orang tersebut positif atau negatif Covid-19.

Saat ini, tercatat menurut data yang dilansir oleh (Tirto.id, 2020) bahwa per tanggal 13 April 2020 tercatat di Indonesia ada 4.557 kasus positif dan juga dilaporkan 380 orang sembuh serta 399 orang lainnya dinyatakan meninggal. Menurut data tersebut, berarti masih ada 3.778 pasien positif Covid-19 atau sekitar 82,9 persen, serta persentase Case Fatality Rate (CFR) atau angka kematian mencapai 8,75 persen. Berdasarkan data tersebut, seperti yang dilansir oleh Putra (2020) menyebutkan bahwasanya provinsi DKI Jakarta masih memegang peringkat tertinggi dengan jumlah kasus positif sebanyak 2186 kasus, disusul oleh Jawa Barat 540 kasus positif, dan peringkat ketiga yakni Jawa Timur dengan 440 kasus positif. Pemerintah juga secara aktif memberlakukan Rapid Test atau tes cepat di berbagai daerah guna mendeteksi dini orang-orang yang terinfeksi Covid-19 namun tidak ditandai dengan gejala atau yang lebih dikenal dengan istilah Orang Tanpa Gejala (OTG). Di Jawa Barat misalnya, seperti rilis data oleh (CNN, 2020), dari 70 ribu alat yang digunakan untuk Rapid Test Covid-19, tercatat ada 832 orang dinyatakan positif.

Kebijakan-kebijakan yang dikeluarkan diharuskan dapat mengurangi permasalahan yang sudah ada, Setidaknya upaya memberantas epidemi maupun pandemi di Indonesia dilakukan melalui

Jurnal Manajemen dan Organisasi Vol. 11 No. 3, Hal. 179-188
Hasem 
tindakan-tindakan, seperti: kewaspadaan diri, penanganan terhadap penderita, sumber penyakit harus dimusnahkan, dan sosialisasi kepada masyarakat. Upaya-upaya yang sistematis yang dilakukan di antaranya adalah perencanaan gerakan skala nasional pemberantasan penyakit dan perjanjianperjanjian skala regional maupun internasional (Sumampouw, 2017). Badan Kesehatan Dunia (WHO) juga membuat rilis panduan yang bersifat sementara sesuai dengan instrumen International Health Regulation 2005 (Organization, 2008) seperti panduan tentang surveilans dan respons, diagnosis via laboratorium, manajemen klinis, tindakan preventif dan tindakan pengendalian infeksi, komunikasi risiko, pola perawatan untuk pasien dengan status dalam pengawasan atau terduga terinfeksi Covid-19, dan pemberdayaan khalayak. Sebelumnya, WHO mengatakan Covid-19 tergolong virus yang eskalasi penyebarannya sangat tinggi juga menyebar di banyak sekali negara sehingga langsung menentukan status Public Health Emergency of International Concern (PHEIC) sejak tanggal 30 Januari 2020 (Tim Kerja Kementerian Dalam Negeri, 2020).

Seperti yang telah diketahui, vaksin untuk Covid-19 sampai sejauh ini masih belum ditemukan. Para ilmuwan masih mencoba mengembangkan vaksin untuk virus yang satu ini. Amerika Serikat sedang mencoba meneliti vaksin yang berbasis RNA juga DNA, sedangkan negara Perancis mencoba melakukan modifikasi vaksin untuk penyakit campak sehingga bisa dipakai untuk menangani Covid-19. Vaksin dipastikan akan hadir tidak dalam waktu dekat-dekat ini, karena vaksin harus melewati serangkaian uji klinis agar terlihat daya kuratifnya (Mardhia et al., 2020). Sambil menunggu adanya vaksin dan jika mengacu pada prediksi dari Sarah Gilbert (Profesor Vaksinologi Oxford University), yang percaya 80 persen vaksin Covid-19 akan ditemukan pada bulan September 2020 menurut yang dilansir oleh CNBC (2020). Pemerintah Indonesia selain mengadakan kegiatan Rapid Test di berbagai daerah, juga aktif memberlakukan tes Polymerase Chain Reaction (PCR), tes ini berupa pemeriksaaan imunoglobulin sebagai upaya tes screening terhadap Covid-19. Bedanya dengan Rapid Test, tes PCR dilakukan dengan pengambilan spesimen lendir, dahak, atau cairan pada nasofaring yang kemudian diteliti dengan cara mengubah RNA menjadi DNA sehingga alat PCR bisa memproses amplifikasi (perbanyakan materi genetik) sehingga mampu mendeteksi RNA virus corona, sedangkan Rapid Test dilakukan hanya dengan mengambil sedikit sampel darah untuk mendeteksi antibodi, yaitu IgM dan IgG yang diproduksi tubuh untuk melawan Covid-19. Namun kalau soal sensitivitas, PCR masih unggul dibanding Rapid Test karena mungkin saja IgM dan IgG yang terbentuk itu karena adanya infeksi virus lain yang bukan Covid-19, akan tetapi PCR membutuhkan waktu yang cukup lama dan metodologi di laboratorium yang rumit (Elvina, 2020; Long et al., 2020).

Adapun beberapa kajian terdahulu oleh Joharudin et al. (2020) yang membahas fenomena panic syndrom dikalangan masyarakat akibat dari mewabahnya virus COVID-19, Nur Rohim Yunus et al. (2020) membahas mengenai kebijakan pemberlakukan lockdown sebagai antisipasi penyebaran virus corona, serta penelitian yang dilakukan oleh Pakpahan (2020) yang membahas dampak dari virus Covid-19 terhadap usaha mikro, kecil dan menengah. Walaupun sudah cukup banyak artikel mengenai Covid-19 tapi masih belum ada yang melihat secara detail akan perencanaan pemerintah dalam empat strategi seperti strategi promotif, preventif, kuratif dan jejaring media sosial dalam rangka menangulangi persebaran virus Covid-19.

Berdasarkan uraian-uraian diatas, artikel ini akan mencoba menjelaskan terkait tindakantindakan yang bisa dilakukan oleh pemerintah baik strategi yang bersifat preventif (pencegahan), promotif (pemberdayaan), dan kuratif (pengobatan) yang berhubungan dengan kesehatan warga negara maupun strategi pemberian Jaring Pengaman Sosial (JPS) di tengah situasi pandemi agar warga negara merasa tercukupi secara ekonomi, karena dampak lain dari pandemik Covid-19 bukan hanya terkait krisis kesehatan akan tetapi krisis ekonomi juga merupakan hal yang pasti terjadi. Dalam hal ini, masyarakat juga harus berperan proaktif dalam mengikuti segala imbauan yang dikeluarkan oleh pemerintah, hal itu penting sebagai bentuk sinergitas antara pemerintah dan masyarakat yang sama-sama harus saling berkolaborasi untuk mempersingkat masa pandemi Covid-19 di Indonesia. 


\section{METODE PENELITIAN}

Metode yang dipakai dalam penelitian yang satu ini adalah metode yang bersifat Kualitatif (Sugiyono, 2013). Maksudnya, jenis metode penelitian yang dapat menjelaskan sesuatu yang berdasar kepada data dan angka yang dipakai untuk penelitian. Selain itu, penelitian ini juga merupakan penelitian pustaka (library research) (Danandjaja, 2014), yang artinya pengumpulan data dari penelitian ini dilakukan dengan cara penelusuran data serta informasi melalui dokumen-dokumen yang tersedia, baik dokumen yang bersifat tertulis seperti foto dan gambar, maupun dokumen elektronik yang dapat mendukung dalam proses penulisan penelitian ini sendiri. Data-data yang disertakan oleh peneliti merupakan data banyaknya jumlah kasus COVID-19 dari sumber yang dianggap kredibel, juga disertai penjelasan mengenai tindakan-tindakan dan kebjiakan-kebijakan pemerintah untuk mengatasi pandemi Covid-19 ini, baik pemerintah ditingkat pusat maupun pemerintah yang ada ditingkat daerah, serta kontribusi dari masyarakat dalam mematuhi segala himbauan yang dikeluarkan oleh pemerintah sebagai bentuk sinergitas antara pemerintah dan rakyatnya.

Menggunakan model analisis Triangulasi (Rahardjo, 2010), peneliti menggabungkan data yang sejenis dan membuat simpulan dari setiap data tersebut menjadi sebuat simpulan yang akhirnya dapat dijadikan narasi yang dapat memudahkan pembaca dalam memahami setiap tujuan-tujuan yang telah penulis tetapkan. Proses ini dapat dilihat pada Gambar 1.

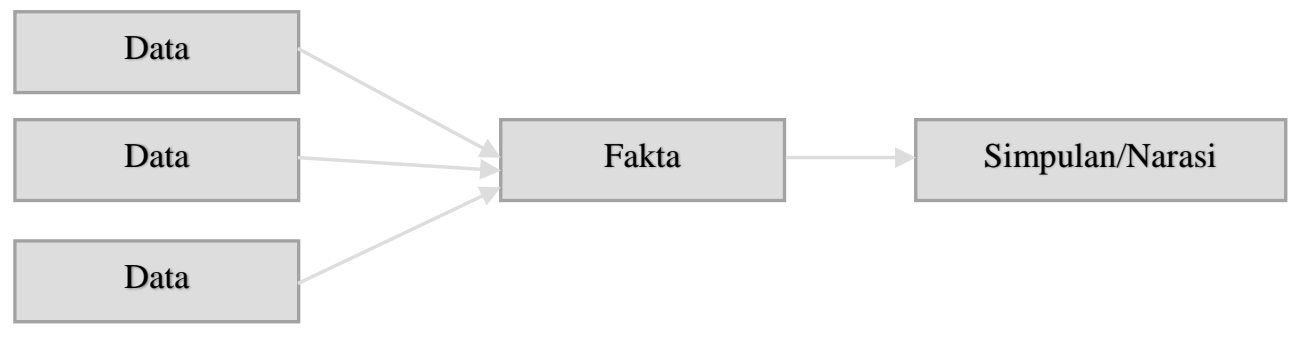

Gambar 1. Proses Triangulasi

\section{HASIL DAN PEMBAHASAN}

\section{COVID-19 dan Persebarannya}

Virus corona atau dikenal juga dengan nama Severe Acute Respiratory Syndrome Coronavirus 2 (SARS-CoV-2) merupakan virus baru yang menginfeksi sistem pernapasan orang yang terjangkit, virus ini umumnya dikenal sebagai Covid-19 (Lai et al., 2020). Virus ini bahkan membuat kita melakukan kebiasaan baru bahkan di Lembaga peradilan dan dunia Pendidikan (Aji, 2020; Sodik, 2020). Virus Corona bisa menyebabkan hal yang fatal terutama bagi mereka yang mengidap gangguan pernapasan sebelumnya akan mengalami sindrom gangguan pada pernapasan tingkat akut walaupun sudah dinyatakan sembuh dari virus ini. Hal itu disebut sebagai efek dalam jangka panjang dari infeksi Covid-19 dan penderita akan menurun fungsi paru-parunya sebanyak 20 sampai 30 persen setelah melewati serangkaian pemulihan. Selain paru-paru ternyata ginjal juga bisa terdampak, penderita Covid-19 dengan persentase 25 sampai 50 persen mengalami gangguan pada ginjal. Penyebabnya adalah protein dan juga sel darah merah akan cenderung lebih banyak. Dengan persentase 15 persen juga pasien Covid-19 cenderung turun fungsi penyaringan pada ginjalnya, serta penyakit ginjal akut juga bisa saja menjadi masalah lain yang akan diderita oleh orang yang terinfeksi Covid-19. Pada sistem saraf juga bisa saja terserang akibat infeksi dari Covid-19, virus ini dapat menyerang sistem pada saraf pusat. Di negara China misalnya orang yang menderita gangguan pada 
sistem saraf mencapai 36 persen dari 214 orang yang dinyatakan positif Covid-19. Gejala-gejala yang timbul seperti pusing dan gangguan di indera pencium serta indera perasa.

Corona Virus Disease 2019 ini awal penyebarannya terjadi di kota Wuhan (Okada et al., 2020), China pada penghujung tahun 2019. Virus ini menyebar dengan sangat masif sehingga hampir semua negara melaporkan penemuan kasus Covid-19, tak terkecuali di negara Indonesia yang kasus pertamanya terjadi di awal bulan Maret 2020. Sehingga merupakan hal yang wajar banyaknya negara yang mengambil kebijakan sesuai dengan situasi dan kondisi di negara masing-masing dan membuat hubungan antara beberapa negara menjadi tidak berjalan baik salah satu nya autrasilia dengan negaranegara pasifik (Laila, 2020), akan tetapi kebijakan yang paling banyak diambil adalah dengan memberlakukan lockdown yang dianggap sebagai strategi tercepat memutus mata rantai penyebaran virus yang satu ini. Berikut adalah data persebaran virus Covid-19 yang penulis dapatkan dari website resmi pemerintahan Indonesia, yang dapat dilihat pada Gambar 2.

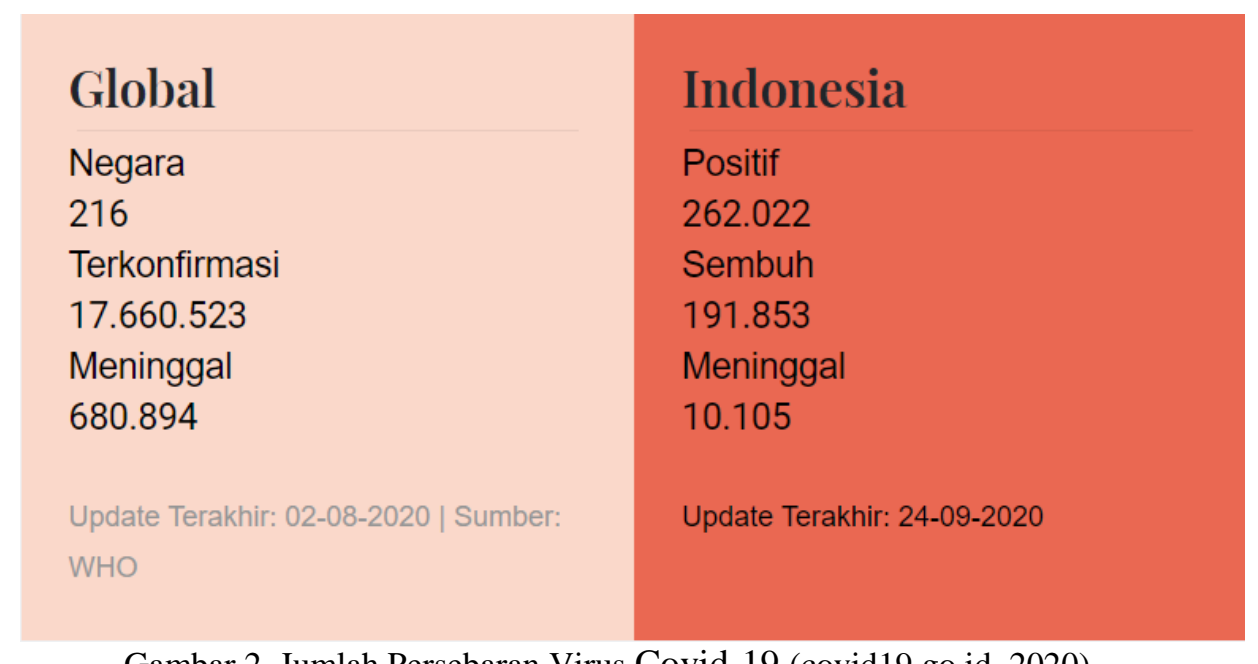

Gambar 2. Jumlah Persebaran Virus Covid-19 (covid19.go.id, 2020)

\section{Kebijakan Pemerintah}

Terkhusus di Indonesia, setidaknya secara garis besar pemerintah telah melakukan berbagai strategi dalam menghambat penambahan kasus positif Covid-19 baru. Adapun strategi-strategi yang diberlakukan oleh pemerintah di Indonesia terbagi menjadi tiga dalam hal kesehatan yaitu dalam bentuk promotif, preventif dan kuratif untuk penanganan penyebaran Covid-19. Selain itu, dalam bidang ekonomi pemerintah juga memberlakukan Jaring Pengaman Sosial untuk membantu warga negara melewati masa krisis ekonomi.

\section{Strategi Promotif}

Pemerintah secara proaktif mengajak warga negara untuk meningkatkan imunitas guna mempersiapkan kondisi tubuh untuk menghadapi virus Covid-19 ini. Berbagai sumber merilis upayaupaya apa saja yang bisa dilakukan oleh masyarakat dalam memperbaiki daya tahan tubuh terhadap infeksi saluran napas. Beberapa di antaranya adalah dengan tidak merokok dan berhenti mengonsumsi alkohol, mengatur pola tidur, serta mengonsumsi suplemen tubuh (Susilo et al., 2020).

Selain itu, pemerintah juga mengimbau warga negara untuk menerapkan Pola Hidup Bersih dan Sehat (PHBS) dengan mengikuti rekomendasi dari Badan Kesehatan Dunia (WHO) dalam menghadapi wabah Covid-19. Langkah-langkah proteksi mendasar seperti cuci tangan secara rutin dengan alkohol atau sabun dengan air, menjaga jarak aman jika ada orang yang terlihat batuk dan bersin, memberlakukan etika batuk dan bersin seperti menutup mulut dengan tangan, dan pergi ke 
rumah sakit untuk melakukan crosscheck apabila terdapat gejala Covid-19 pada tubuh. Anjuran jarak aman untuk memenuhi kaidah physical distancing minimal satu meter karena tujuannya agar tidak terjadi penyebaran yang dipengaruhi oleh droplets penderita Covid-19. Pasien rawat inap yang ada indikasi terinfeksi Covid-19 juga harus diberlakukan jarak aman minimal satu meter tersebut dengan pasien atau petugas medis, dipakaikan masker khusus medis, diberi arahan mengenai etika batuk/bersin, dan dicontohkan cara cuci tangan yang baik dan benar (Susilo et al., 2020).

\section{Strategi Preventif}

Presiden mendirikan gugus tugas khusus percepatan penanganan Covid-19 yang difungsikan sebagai juru teknis penanganan pandemi Covid-19 dan dukungan penuh dari seluruh aspek pertahanan. Dikala negara lain menerapkan karantina wilayah atau lockdown, pemerintah Indonesia melalui Kementerian Kesehatan (kemenkes) menerapkan kebijakan Pembatasan Sosial Berskala Besar (PSBB) melalui Permenkes 9 tahun 2020 mengenai Panduan PSBB dalam rangka percepatan penanganan Covid-19 dan sebelumnya menerapkan social distancing serta physical distancing bagi masyarakat. Pembatasan Sosial Berskala Besar merupakan suatu langkah yang cukup strategis untuk diambil oleh pemerintah dengan bertujuan menekan laju dari penularan Covid-19 di Indonesia ini (Thorik, 2020)

Individu yang merasa pernah ada kontak dengan pasien yang dinyatakan positif Covid-19 juga harus memeriksakan dirinya ke fasilitas kesehatan yang nantinya dilakukan serangkaian tes menggunakan metode rapid test terlebih dahulu dan nantinya jika reaktif akan dilakukan tes PCR, apabila orang tersebut mengalami gejala ringan bisa melakukan self-isolation dan jika gejalanya berat harus dirawat di rumah sakit rujukan Covid-19. Badan Kesehatan Dunia juga sudah merilis panduan penilaian risiko bagi petugas medis yang merawat pasien positif Covid-19 sebagai pedoman tindakan lanjutan. Bagi kelompok pasien Covid-19 yang berisiko tinggi, direkomendasikan agar ada isolasi di fasilitas kesehatan total dalam jangka waktu 14 hari dan terus dipantau petugas medis dan diberi pertolongan yang bisa membantu pasien Covid-19 agar cepat sembuh. Pada kelompok pasien Covid19 yang berisiko rendah, diimbau melaksanakan self-isolation dengan selalu memerhatikan suhu tubuh dan sistem pernafasan selama 14 hari, apabila keluhan memberat harus segera minta tim medis menjemput agar bisa ditangani di fasilitas kesehatan. Pada masyarakat umum, upaya mitigasi dilaksanakan dengan tidak berkerumun dalam jumlah besar (social distancing) dan selalu jaga jarak aman satu meter (physical distancing). (Susilo et al., 2020)

SARS-CoV-2 menular terutama melalui droplets. Alat pelindung diri (APD) merupakan salah satu strategi pencegahan penularan selama penggunaannya rasional (Susilo et al., 2020). Selain itu Badan Kesehatan Dunia menyatakan bahwasanya masker non medis dapat dijadikan salah satu Alat Pelindung Diri (APD) untuk masyarakat yang sehat untuk menghindari paparan droplets dari penderita Covid-19 yang masih berkeliaran di lingkungan, sedangkan masker medis ditekankan hanya digunakan oleh para petugas medis (World Health Organization, 2020).

\section{Strategi Kuratif}

Seperti yang dikatakan oleh Prof. Dr. dr. Faisal Yunus Sp.P (K), FCCP kepada (Kumparan, 2020). Beliau mengatakan ada beberapa treatment yang diberikan kepada pasien Covid-19 contohnya adalah dengan pemberian obat yang dahulu pernah dipakai untuk wabah sebelum penyakit Sars-CoV2 seperti obat oseltamivir untuk wabah fluburung. Bagi pasien Covid-19 yang menderita pneumonia dilakukan intervensi medis berupa pemberian antibiotik dan juga mereka diminta mengonsumsi vitamin $\mathrm{C}$ dengan dosis tinggi di bawah pengawasan dokter. Apabila pasien menderita gangguan pada hati akan diberikan hepatoprotector yang merupakan senyawa obat yang dapat memproteksi hati dari kerusakan akibat virus. 
Selain itu, Presiden Joko Widodo juga mengatakan bahwa Indonesia akan memakai avigan dan klorokuin untuk mengobati pasien Covid-19. Klorokuin misalnya, sebelumnya dikenal sebagai obat untuk menyembuhkan penyakit jenis malaria. Menurut Dr.Keri Lestari, M.Si,Apt. penggunaan obat yang sedianya digunakan untuk penyakit tertentu dan sekarang dipakai untuk penyakit lain merupakan hal yang lumrah di dunia medis, istilahnya dikenal sebagai repurposing drug. Di dunia internasional, penggunaan obat jenis ini untuk menangani wabah Covid-19 mendapat sorotan dari Pengawas Obat dan Makanan AS (FDA). FDA mengatakan bahwa klorokuin belum disetujui sebagai obat virus corona, akan tetapi penggunaannya tetap diperbolehkan dengan seizin pasien corona itu sendiri.

\section{Strategi Jaring Pengaman Sosial}

Perppu Nomor 1 Tahun 2020 tentang Kebijakan Keuangan Negara dan Stabilitas Sistem Keuangan untuk Penanganan Pandemi Covid-19 yang diterbitkan oleh pemerintah sebetulnya lebih banyak memuat terkait pengaturan kebijakan keuangan antara pusat dan daerah, stabilitas sistem keuangan, kebijakan perpajakan, pemulihan perekonomian nasional, dsb. Sedangkan untuk Jaring Pengaman Sosial hanya disinggung sedikit dan hanya berupa pasal yang menyebutkan dana desa bisa digunakan untuk Bantuan Langsung Tunai (BLT) kepada penduduk miskin di tingkat desa dan program percepatan penanganan Covid-19 (Maftuchan, 2020).

Pemerintah melalui konferensi pers yang dilakukan oleh Presiden Joko Widodo per tanggal 31 Maret 2020 mengumumkan skema Jaring Pengaman Sosial yang akan berlaku untuk membantu masyarakat di tengah pandemi, hal ini dinilai oleh berbagai kalangan tak kalah pentingnya dengan strategi-strategi yang berhubungan dengan kesehatan karena dengan ekonomi yang terjamin membuat efektivitas dari program seperti PSBB bisa terjamin. Adapun rincian skema bantuannya adalah sebagai berikut; (1). Program Keluarga Harapan (PKH) yang penerima manfaatnya ditingkatkan dari 9,2 juta menjadi 10 juta dengan besaran manfaatnya meningkat 25 persen dari yang sebelumnya. Seperti untuk ibu hamil naik dari Rp. 2.400.000,00 menjadi Rp. 3.000.000,00 per tahun, keluarga dengan anak usia dini sebesar Rp. 3.000.000,00 per tahun, keluarga dengan disabilitas Rp. 2.400.000,00 per tahun. Kebijakan ini telah efektif sejak bulan April 2020 dengan anggaran yang dialokasikan sebesar 37,4 Triliun; (2). Bantuan Pangan Non-Tunai (BPNT). Pemerintah meningkatkan juga penerima bantuan jenis ini dari 15,2 juta menjadi 20 juta dengan diikuti naiknya persentase besaran bantuan 30 persen dari yang tadinya Rp. $150.000,00$ per penerima menjadi Rp. 200.000,00 per penerima; (3). Kartu Prakerja, untuk jenis bantuan ini juga ternyata pemerintah menaikkan anggarannya dari yang sebelumnya hanya sebesar Rp. 10 triliun menjadi Rp. 20 triliun, penerima manfaatnya sebanyak 5,6 juta orang dengan sasaran pekerja informal dan pelaku Usaha Mikro Kecil Menengah (UMKM) dengan nilai manfaat antara Rp. 650.000,00 - Rp. 1.000.000,00 per bulan dan berlaku selama empat bulan; (4). Bantuan Subsidi Listrik, Pemerintah memberi subsidi penuh terhadap pelanggan listrik bertegangan 450 VA yang jika dilihat dari jumlah penggunanya sebanyak 24 Juta. Pemerintah juga bersubsidi 50 persen bagi pengguna listrik bertegangan 900 VA yang jumlah penggunanya sebanyak 7 Juta pelanggan. Kedua jenis subsidi listrik tersebut sama-sama berlaku tiga bulan mulai dari April hingga Juni 2020; (5). Alokasi cadangan anggaran, dana sebesar Rp 25 Triliun akan digunakan untuk melakukan pemenuhan kebutuhan pokok, operasi pasar dan logistik; (6). Pemerintah akan memberi keringanan kredit dibawah 10 miliar untuk pekerja sektor informal dan pelaku UMKM (Maftuchan, 2020).

\section{Analisis Sinergitas Antara Pemerintah dan Masyarakat}

Apabila berbicara juga mengenai kesehatan selama pandemi Covid-19, menurut Badan

urnal Manajemen dan Organisas

Vol. 11 No. 3

Desember 2020

Hal. $179-188$
Kesehatan Dunia dinyatakan bahwa "memperoleh derajat kesehatan yang setinggi-tingginya adalah suatu hak asasi bagi setiap orang". Berdasarkan penjelasan tersebut, maka kesehatan merupakan fundamental rights atau hak mendasar. Kewajiban untuk menjunjung tinggi hak kesehatan warga negara sudah pasti dibebankan kepada pemerintah, menurut Badan Kesehatan Dunia "government 
has a responsibility for the health of their people which can be fullfilled only by the provision of adequate health and social measure" (Nurhalimah, 2020).

Sudah jelas bahwasanya dalam menentukan arah kebijakan selama pandemi Covid-19 prioritas pemerintah harus mengacu kepada bidang kesehatan bukan kepada bidang lain semisal ekonomi. Hal ini penting dalam menjamin kesehatan warga negara karena ekonomi masih bisa di bangkitkan lagi ketika masa pandemi Covid-19 selesai, akan tetapi warga negara yang menjadi korban jiwa sudah tidak bisa dikembalikan lagi pastinya. Karena sebenarnya dalam slogan hukum juga sudah jelas ditegaskan bahwa keselamatan warga adalah hukum tertinggi atau Salus Populi Suprema Lex Esto.

Saat ini setelah PSBB diberlakukan di berbagai daerah selama kurang lebih dua bulan, kini pemerintah pusat dan daerah mulai melakukan relaksasi dengan dua opsi kebijakan yang terdiri dari; (1). PSBL (Pembatasan Sosial Berskala Lokal), pemberlakuannya ada dilokus kecil seperti RT atau RW dengan status zona merah, contohnya seperti informasi yang diambil melalui (Vivanews.com, 2020), RT 05 RW 04 di Petamburan yang masuk kategori zona merah memberlakukan kebijakan ini, teknisnya tidak jauh beda sebetulnya dengan PSBB, hanya saja cakupannya yang berbeda karena dilakukan di skala RT atau RW, hal-hal yang dilakukan warga diantaranya adalah melakukan penutupan akses keluar masuk, pemberian masker bagi warga yang keluar rumah, pembuatan tempat cuci tangan, dsb; (2). New normal life (Tatanan kehidupan normal yang baru), opsi yang satu ini cukup kontroversial karena diberlakukan disaat angka penambahan kasus positif masih terbilang banyak tiap harinya, konsep ini dikemukakan pertama kali ketika Presiden Joko Widodo memberi keterangannya di Istana Merdeka, beliau mengatakan bahwa "Sampai nanti ditemukan vaksin yang efektif untuk Covid-19, maka kita harus hidup dengan berdamai bersama Covid-19 untuk beberapa waktu kedepan". Narasi yang dipakai oleh Presiden Joko Widodo tersebut menurut Deputi Bidang Protokol, Pers, serta Media di Sekretariat Presiden, Boy Machmudin, memiliki arti penyesuaian dengan tatanan kehidupan normal yang baru. Pada tataran konsep, yang dimaksud dengan new normal life adalah masyarakat melakukan aktivitas seperti sebelum ada pandemi Covid-19 akan tetapi diatur dengan protokol kesehatan yang sangat ketat seperti physical distancing, menggunakan masker saat bepergian, social distancing, serta mencuci tangan setiap waktu. Menurut Wiku selaku ketua Tim Pakar Gugas Percepetan Penanganan Covid-19, new normal life adalah sebuah perubahan atas perilaku masyarakat untuk tetap menjalankan aktivitas tapi dengan protokol kesehatan ketat agar mencegah menularnya Covid-19 (Indonesia.go.id, 2020).

Relaksasi PSBB memang sangat kontraproduktif dengan situasi dan kondisi yang sebetulnya belum cukup aman dilaksanakannya kebijakan tersebut. Akan tetapi jika pemerintah sudah menetapkan protokol kesehatan selama fase PSBL maupun new normal life, seyogyanya masyarakat mengikuti imbauan tersebut, karena jika sudah tidak ada lagi intervensi pemerintah terhadap arus mobilitas warga diluar maka prinsip kehati-hatian harus ditingkatkan, karena bisa jadi banyak orang yang menjadi carrier Covid-19. Maka dari itu pemerintah tak henti-hentinya mengingatkan masyarakat terkait bahaya tersebut dan meminta masyarakat agar berdiam diri di rumah saja apabila tidak ada aktivitas yang mendesak, sekarang tinggal bagaimana masyarakat berpikir secara logis dan rasional dalam menyikapi hal ini. Jangan sampai terjadi bias kognitif, bias kognitif itu sendiri adalah suatu kesalahan terstruktur dalam cara pikir yang mempengaruhi penilaian dan keputusan yang dipakai seseorang (Buana, 2020). Masyarakat harus menghindari pemikiran yang bias tersebut, karena cepat atau lambatnya masa pandemi Covid-19 juga selain dipengaruhi oleh pengaturan kebijakan dari pemerintah juga dipengaruhi oleh kedisiplinan masyarakat dalam mematuhinya.

\section{KESIMPULAN}

Jurnal Manajemen dan Organisasi

Vol. 11 No. 3 , Vol. 11 No. 3,

Sinergitas antara pemerintah dan masyarakat merupakan hal utama dalam menangulangi penyebaran wabah Covid-19, Sebagaimana diketahui pemerintah merelaksasi PSBB dan 
mengeluarkan dua opsi yakni Pembatasan Sosial Berskala Lokal (PSBL) tingkat RT atau RW dan new normal life atau tatanan kehidupan normal yang baru yang mana kedua kebijakan ini sangat tergantung dari peran serta masyarakat untuk taat mengikutinya. Untuk peran pimpinan daerah seperti RT/RW merupakan hal pokok utama yang dapat dikondisikan pemerintah dalam mengupayakan sinergitas antara pemerintah dan masyarakat dapat terjadi.

\section{DAFTAR PUSTAKA}

Aji, R. H. S. (2020). Dampak Covid-19 pada Pendidikan di Indonesia: Sekolah, Keterampilan, dan Proses Pembelajaran. Salam: Jurnal Sosial Dan Budaya Syar-i, 7(5), 395-402.

Arum, R. (2020). Pembatasan Sosial di Indonesia Akibat Virus Corona Ditinjau dari Sudut Pandang Politik. LawArXiv. https://doi.org/10.31228/osf.io/g8ny3

Buana, D. R. (2020). Analisis Perilaku Masyarakat Indonesia dalam Menghadapi Pandemi Virus Corona (Covid-19) dan Kiat Menjaga Kesejahteraan Jiwa. SALAM: Jurnal Sosial Dan Budaya Syar-I, 7(3), 217-226. https://doi.org/10.15408/sjsbs.v7i3.15082

CNBC. (2020). Mohon Doanya, Obat Vaksin Covid-19 Siap September Ini.

CNN. (2020). Hasil Rapid Test Jawa Barat, 832 Orang Positif Corona. covid19.go.id. (2020). Data Sebaran COVID-19. Retrieved September 25, 2020, from https://covid19.go.id/ website: https://covid19.go.id/

Danandjaja, J. (2014). Metode Penelitian Kepustakaan. Antropologi Indonesia, 53, 82-92.

Elvina, L. (2020). Ini Bedanya Rapid Test dan PCR Untuk Pemeriksaan Virus Corona. Kompas TV.

Joharudin, A., Septiadi, M. A., Maharani, S., Aisi, T. D., \& Nurwahyuningsih, N. (2020). PANIC SYNDROM COVID-19: PENEKANAN TERHADAP KEBIJAKAN YANG DIBERIKAN. Jurnal Perspektif, 4(1), 44-53.

Lai, C.-C., Shih, T.-P., Ko, W.-C., Tang, H.-J., \& Hsueh, P.-R. (2020). Severe acute respiratory syndrome coronavirus 2 (SARS-CoV-2) and corona virus disease-2019 (COVID-19): the epidemic and the challenges. International Journal of Antimicrobial Agents, 55(3), 105924.

Laila, N. N. (2020). Hubungan Luar Negeri Australia dengan Negara-Negara Pasifik dalam Bidang Ekonomi Periode 2012-2018. Khazanah Sosial, 2(2), 78-87.

Long, C., Xu, H., Shen, Q., Zhang, X., Fan, B., Wang, C., ... Li, H. (2020). Diagnosis of the Coronavirus disease (COVID-19): rRT-PCR or CT?. European Journal of Radiology, 126, 108961.

Maftuchan, A. (2020). Program Tunai di Era COVID-19: Bantuan Tunai Korona atau Jaminan Penghasilan Semesta. Program Tunai Di Era COVID-19: Bantuan Tunai Korona Atau Jaminan Penghasilan Semesta.

Mardhia, D., Kautsari, N., Syaputra, L. I., Ramdhani, W., \& Rasiardhi, C. O. (2020). Penerapan Protokol Kesehatan dan Dampak Covid-19 Terhadap Harga Komoditas Perikanan dan Aktivitas Penangkapan. Indonesian Journal of Applied Science and Technology, 1(2), 80-87.

Nurhalimah, N. (2020). Upaya Bela Negara Melalui Sosial Distancing Dan Lockdown Untuk Mengatasi Wabah Covid-19 (Efforts to Defend the Country Through Social Distancing and Lockdown to Overcome the COVID-19 Plague). Available at SSRN 3576405.

Nurhalimah, S. (2020). Covid-19 dan Hak Masyarakat atas Kesehatan. SALAM: Jurnal Sosial Dan Budaya Syar-I, 7(6), 543-554. https://doi.org/10.15408/sjsbs.v7i6.15324

Okada, P., Buathong, R., Phuygun, S., Thanadachakul, T., Parnmen, S., Wongboot, W., ... Vachiraphan, A. (2020). Early transmission patterns of coronavirus disease 2019 (COVID-19)

Jurnal Manajemen dan Organisasi

Vol. 11 No. 3 ,

Desember 2020 Hal. $179-188$ in travellers from Wuhan to Thailand, January 2020. Eurosurveillance, 25(8), 2000097.

Organization, W. H. (2008). International health regulations (2005). World Health Organization.

Pakpahan, A. K. (2020). Covid-19 Dan Implikasi Bagi Usaha Mikro, Kecil, Dan Menengah. Jurnal Ilmiah Hubungan Internasional, 59-64. 
Putra, N. P. (2020). Sebaran Data Pasien Positif Covid-19 Per 13 April 2020, Terbanyak Masih di Jakarta. Liputan 6.com.

Rahardjo, M. (2010). Triangulasi dalam penelitian kualitatif. Malang: Sekolah Pascasarjana Universitas Islam Negeri Maulana Malik Ibrahim.

Sodik, A. A. (2020). JUSTICIABELEN: Penegakan Hukum di Institusi Pengadilan dalam menghadapi Pandemi Covid-19. Khazanah Hukum, 2(2), 56-64.

Sugiyono. (2013). Metode Penelitian Pendidikan Pendekatan Kauntitatif, kualitatif dan R\&D. Bandung: Alfabeta.

Sumampouw, O. J. (2017). Pemberantasan Penyakit Menular. Yogyakarta: Deepublish.

Susilo, A., Rumende, C. M., Pitoyo, C. W., Santoso, W. D., Yulianti, M., Herikurniawan, H., ... Yunihastuti, E. (2020). Coronavirus Disease 2019: Tinjauan Literatur Terkini. Jurnal Penyakit Dalam Indonesia, 7(1), 45-67. https://doi.org/10.7454/jpdi.v7i1.415

Susilo, A., Rumende, C. M., Pitoyo, C. W., Santoso, W. D., Yulianti, M., Sinto, R., .. Cipto, R. (2020). Coronavirus Disease 2019: Tinjauan Literatur Terkini Coronavirus Disease 2019: Review of Current Literatures. Jurnal Penyakit Dalam Indonesia, 7(1), 45-67.

Thorik, S. H. (2020). Efektivitas Pembatasan Sosial Berskala Besar Di Indonesia Dalam Penanggulangan Pandemi Covid-19. Jurnal Adalah : Buletin Hukum Dan Keadilan, 4(1), 115120.

Tim Kerja Kementerian Dalam Negeri. (2020). Pedoman umum menghadapi PANDEMI COVID-19 bagi pemerintah daerah: pencegahan, pengendalian, diagnosis dan manajemen. Tim Kerja Kementerian Dalam Negeri Untuk Dukungan Gugus Tugas COVID-19.

Tirto.id. (2020). Update Corono 13 April 2020 Indonesia \& Dunia: Info Data Hari Ini.

Yunus, N. R., \& Rezki, A. (2020). Kebijakan Pemberlakuan Lock Down Sebagai Antisipasi Penyebaran Corona Virus Covid-19. SALAM: Jurnal Sosial Dan Budaya Syar-I, 7(3), 227238. 